\title{
The Effects of Helicobacter Pylori Infection on Nutrition Status and Metabolism
}

\author{
Helicobacter Pylori Enfeksiyonunun Beslenme Durumu ve Metabolizma Üzerine Etkileri
}

\author{
Ayçıl Özturan, Saniye Bilici \\ Gazi University, Health Science Faculty, Department of Nutrition and Dietetics, Ankara, Turkey
}

\begin{abstract}
H.pylori infection, which is common in the world as well as in our country and has been identified as a group 1 carcinogen by the World Health Organization (WHO) is a Gram negative pathogen. Low socio-economic level, low consumption of fruits and fresh vegetables, increased consumption of fast food, tobacco use and poor oral hygiene are reported risk factors for H.pylori infection. It is considered that distruption of the absorption of some micronutrients affected the appetite and food intake because of due to changing ghrelin and leptin hormone levels in the presence of H.pylori. Also, some studies showed that H.pylori infection is effective in the development or progression of gastrointestinal diseases, metabolic syndrome, insulin resistance, diabetes and diabetes complications. Some foodstuffs and nutrients are thought to have infection-protective and/or having preventive effects and recent studies have focused on these subject. It is mentioned that especially fresh fruits, vegetables and some probiotic formulation can play an important role in the treatment of H.pylori infection. The relationship between nutrition and H.pylori infection and its metabolic effects of H.pylori will be discussed in this review.
\end{abstract}

Key words: Helicobacter pylori; ghrelin; appetite; nutrition; nutrients

\section{ÖZET}

H.pylori ülkemizde ve dünyada yaygın olarak görülen ve Dünya Sağlık Örgütü (DSÖ) tarafından 1. sınıf karsinojen olarak tanımlanan Gram negatif bir patojendir. Düșük sosyo ekonomik düzey, taze sebze, meyve tüketiminin az ve fast food tüketiminin fazla olması, yetersiz ağız hijyeni ve sigara kullanımının H.pylori enfeksiyonuna yakalanma riskini arttırdığı bildirilmektedir. H.pylori varlığında ghrelin ve leptin hormonlarının seviyelerindeki değișiklik nedeniyle iștah ve besin alımını etkilemekte, bazı mikro besin öğelerinin emilimini bozmaktadır. Ayrıca yapılan çalıșmalarda gastrointestinal sistem hastalıkları, metabolik sendrom, insülin direnci, diyabet ve diyabetin komplikasyonlarının gelișimi veya ilerlemesinde H.pylori enfeksiyonunun etkili olduğu gösterilmektedir. H.pylori enfeksiyonunda bazı besinlerin ve besin öğelerinin koruyucu ve/veya önleyici etki gösterdiği düșünülmekte ve bu konuda yapılan çalıșmaların sayısı her geçen gün artmaktadır.

Ayçl Özturan, Emniyet Mah. Muammer Yasar Bostancı Cad. No: 16, Beşevler, Ankara, Türkiye, Tel.05556401155Email.aycilozturan@gmail.com

Geliş Taribi: 26.04.2016 • Kabul Taribi: 02.04.2017
Özellikle taze meyve, sebzeler ve bazı probiyotik formülaların H.pylori enfeksiyonu tedavisinde önemli rol oynadığından bahsedilmektedir. Bu derlemede de H.pylori enfeksiyonunun beslenme durumu ile ilișkisi ve metabolizma üzerine etkileri irdelenecektir.

Anahtar kelimeler: Helicobacter pylori; ghrelin; iștah; beslenme; besin öğesi

\section{Introduction}

Known as a Gram negative pathogen, H.pylori, which is common in the world as well as in our country, affects more than about $50 \%$ of population ${ }^{1}$. More than $80 \%$ of the population in developing countries and $20-80 \%$ in developed countries suffers from this bacteria and its effects $^{2}$. In Turkey, the frequency of H.pylori infection have reported to be approximately $70-80 \%$ according to the recent studies ${ }^{3,4}$. Urea breath test, stool antigen scanning and endoscopic evaluation is used in the diagnosis of $H$.pylori infection ${ }^{5}$. The incidence of infection has been increasing with age since the early years and those who have lived under poor socioeconomic conditions especially in childhood are at a more risk of H.pylori infection in the following years ${ }^{6}$. Low socioeconomic status, low consumption of fresh vegetables and fruits, increased fast food consumption, poor oral hygiene and tobacco use are known as risk factors for H.pylori infection ${ }^{3,4,7-10}$ as well as alcohol use but, present data are contradictory ${ }^{9,11}$.

H.pylori, identified as a group 1 carcinogen by the WHO plays an important role especially in the development of gastric cancer and mucosal-associated lymphoid tissue lymphoma ${ }^{5}$. H.pylori colonize in the epithelial cell lining of the stomach by affecting the human gastric flora that disrupts the gastric mucosal integrity. The presence of bacteria affect the levels of ghrelin and leptin hormones results in negative effects on appetite and food intake ${ }^{12}$. Some micronutrient malabsorptions, especially folate, 
homocysteine and iron deficiency can develop in the presence of H.pylori infection ${ }^{2}$.

Specific foods and nutrients have protective and/or preventive effects in the development or progession of the infection. Especially fresh vegetables and fruits can play an important role in the treatment of H.pylori infection ${ }^{5}$. Honey and green/black tea consumption has also been shown to be associated with reduced prevelance of H.pylori infection ${ }^{13}$.

H.pylori infection has an important role in terms of public health because of its worlwide distribution and high level of prevalence and the importance of associated pathologies according with gastroduodenal diseases ${ }^{14}$. Besides the gastrointestinal diseases, H.pylori can be associated with diabetes and development of diabetic complications, metabolic syndrome and insulin resistance also ${ }^{15}$. So, this paper aims to discuss the relationship between nutrition and $\mathrm{H}$.pylori infection and its metabolic effects of $H$.pylori.

\section{Pathophysiology of H.pylori and Its Effect on Appetite}

H.pylori colonizes in the gastric epithelium and has an important urease activity that leads to the production of ammonia in order to protect itself from gastric acidity. It also produces enzymes such as glicosulfatase, phospholipase A2 and C, which play an important role in the development of gastric mucosal damage. H.pylori leads to an inflammatory response through the gastric epithelium with the production of proinflammatory cytokines such as interleukin 8 and interleukin $1 \beta^{2}$. H.pylori has various virulence factors that play an important role in the pathogenesis of infection. Especially vacuolating toxin $\mathrm{A}$ (Vac-A) and cytotoxinassociated gene $\mathrm{A}(\mathrm{Cag}-\mathrm{A})$ positive are associated with greater pathogenicity and more severe disease ${ }^{2,14}$. CagA positive strains cause a stronger inflammatory response of gastric mucosa with increasing of proinflammatory cytokines. On the other hand, the VacA gene is responsible for vacuolization and apoptosis of gastric epithelial cells. H.pylori infection reduces the gastrointestinal hormones and the absorption or bioavailability of essential nutrients and H.pylori is associated with metabolic balance also. Additionally, H.pylori infection plays a role in changing ghrelin and leptin levels ${ }^{2}$.

Ghrelin peptide is constituted of 28 amino acids with a fatty acid chain modification (octanoyl group) on the third amino acid. Ghrelin peptide was originally isolated from the stomach, but ghrelin protein has also been identified in other peripheral tissues. The acylated forms of ghrelin have been recognised as the major active orexigenic molecules regulating energy balance. When studying the effects of ghrelin on energy balance, differential influences of the acylated and non-acylated forms of the peptide must be considered ${ }^{16,17}$. While active form of ghrelin regulates growth hormone-releasing and food intake, inactive form of ghrelin is effective on cell proliferation and adipogenesis. Acylated ghrelin increases the food intake and involves in positive energy balance. On the other hand, des-acylated ghrelin decreases food intake and devoid of any endocrine activities ${ }^{18,19}$.

The presence of H.pylori on the gastric mucosa affect the levels of ghrelin and leptin hormones results in negative effects on appetite and food intake. Leptin concentrations were higher, ghrelin concentrations and ghrelin/ obestatin ratios were lower in the H.pylori-positive group than in the H.pylori-negative group. Additionally, appetite was decreased in H.pylori positive group ${ }^{12,20}$. After the eradication of H.pylori, ghrelin levels and appetite was increased that results in body weight gain ${ }^{21,22}$. Ghrelin levels and body mass index (BMI) was lower in H.pylori positive group than H.pylori negative group in older ages and H.pylori infection may be one of the underlying causes of malnutrition in the elderly ${ }^{23}$.

The relationship between H.pylori infection and gastric hormones has also been investigated. The effect of H.pylori on ghrelin production has been associated with H.pylori virulence. The extent of gastric damage and level of the infection has been thought to play a key role in the modulation of ghrelin levels. Increased leptin and gastrin levels, decreased plasma ghrelin levels and a negative effect on appetite and dyspeptic symptoms were found to be the consequences of gastric mucosal damage due to H.pylori ${ }^{2}$.

\section{H. Pylori and Absorption Disorders}

H.pylori in the gastric mucosa can cause a malabsorption of certain vitamins and minerals. In several studies, vitamin $\mathrm{B}_{12}$ and folate deficiency was found in H.pylori positive patients compared with healthy individuals ${ }^{2,24,25}$. Reduction of gastric acid secretion, deficiency of ascorbic acid and blocking of iron binding protein lead to iron deficiency in patients with H.pylori ${ }^{26}$. Iron deficiency and anemia were seen more frequently especially in children ${ }^{27,28}$. Hypochlorhydria (reduction of HCL production in stomach) decreases iron absorption by reducing the availability of ascorbic acid. So that, it decreases the absoption of non-heme 
iron leading to the reduction in the transformation of ferric to ferrous form and using iron by H.pylori strains as a growth factor in patients with H.pylori. It may be the main reason for iron deficiency ${ }^{2}$. Absorbtion can be decreased due to the change in gastric physiology ${ }^{29}$. Also, the increase in gastric $\mathrm{pH}$ reduces the iron solubility and iron absorbtion will be affected by reducing the bioavailability of vitamin $\mathrm{B}_{12}$ and folic acid ${ }^{30}$.

The presence of H.pylori on the gastric mucosa affect the levels of vitamin C. Induced by H.pylori, chronic gastritis may be associated with hypochlorhydria and accompanied by low levels of vitamin $C$ in plasma and gastric juice both in adults and children. Vitamin C levels in whole blood, plasma and the gastric juice $\mathrm{pH}$ in Korean children are closely related to the severity of H.pylori infection and the histologic changes in the stomach ${ }^{31}$. High concentration of vitamin $\mathrm{C}$ in gastric juice might inactivate H.pylori urease, the key enzyme for the pathogen's survival and colonization into acidic stomach. Moreover higher prevalence of $H$.pylori infection is related with low serum Vitamin C levels and gastric juice ${ }^{29,32}$.

Vitamin $B_{12}$ deficiency due to food-cobalamin malabsorption is associated with gastritis originating from H.pylori. Decreased secretion of intrinsic factor by parietal cells may be the probable cause of cobalamin malabsorption and atrophic gastritis secondary to $H$. Pylori infection is one explanation for vitamin $\mathrm{B}_{12}$ malabsorption. Low acid-pepsin secretion results in decreased release of free vitamin $B_{12}$ from food proteins and/or promotes overgrowth of bacteria that bind vitamin $B_{12}$ for their own use in the hypochlorhydric stomach and small intestine ${ }^{33,34}$. In a study, H.pylori was detected in $56 \%$ of 138 patients with vitamin $B_{12}$ deficiency and eradication of H.pylori infection successfully improved anemia and serum vitamin $B_{12}$ levels in $40 \%$ of 77 infected patients ${ }^{35}$.

There is a concern about the relationship between $\beta$-carotene bioavailability and H.pylori infection. In the presence of H.pylori, hypochlorhydria and achlorhydria significantly decreased $\beta$-carotene bioavalability $^{36}$. H.pylori infection and low $\beta$-carotene in plasma contribute to the increased risk of gastric atrophy, indicating that $H$.pylori infection might be associated with low plasma $\beta$-carotene ${ }^{37}$.

\section{Effects of Nutrition on the Prevention and Eradication of $\mathrm{H}$. Pylori Infection}

Some nutritional regimens may reduce the virulence of H.pylori infection. Some food items like fruits and vegetables, special spices, bee products (e.g. honey and propolis) and probiotics are supposed to have positive health impacts ${ }^{5}$. Fruits and vegetables have been mentioned as anti H.pylori agents according to their content of antioxidant compounds like bioflavonoids, phytochemicals and ascorbic acid as well as honey, which is known to have antimicrobial activity due to its hydrogen peroxide and non-peroxide components. Also, green tea has positive effects on the prevention of H.pylori due to its polyphenolic catechins content ${ }^{5}$. Additionally, tea catechins may have antibacterial effects against H.pylori and therapeutic effects against gastric mucosal injury ${ }^{38}$. Foods/drinks containing polyphenols such as red wine and green tea have an inhibiting effect on the urease activity of H.pylori and thus being effective on mitigating the related symptoms ${ }^{39}$. There was a positive corelation between daily consumption of sausage, mayonnaise, soft drinks and burgers with the incidence of $H$.pylori infection. Lower consumption of fresh fruits and vegetables are an important risk factor for the development of H.pylori infection. In addition, fish, honey, olive oil, peans and beans are suggested to have negatively correlation with H.pylori infection ${ }^{8}$.

Increased salt consumption is a risk factor for gastric cancer and associated with H.pylori. H.pylori infected individuals with a higher salt consumption had a risk of early gastric cancer 10 fold more than H.pylori negative individuals with a low salt consumption, and the consumption of fruits and vegetables reduced the risk of gastric cancer ${ }^{40}$.

Milk and dairy products are another food items supposed to have protective effects against H.pylori infection and may support the treatment. Especially fermented milk-based probiotics, bovine lactoferrin, immunoglobulin-enriched $\alpha$-lactalbumin and whey protein have been shown to have beneficial effects on the treatment of H.pylori ${ }^{5,41}$. Because of limited data on the benefits of milk and dairy products on H.pylori, further studies should be performed to determine the optimal dose and duration of these food items providing clinically useful effects.

Recent studies have focused on broccoli sprouts, manuka honey, blackcurrant oil and omega-3 oil. Isothiocyanaterich broccoli sprout was found the most effective food against H.pylori. Additionally, the broccoli sprouts are most effective when used alone it has sinergetic effect with omega- 3 or manuka honey ${ }^{42,43}$. Also, these nutrients may decrease inflammation related to H.pylori by blocking the release of IL-8 from gastric epithelial cells ${ }^{43}$. The 
bacteriostatic effects of isothiocyanate sulphoraphane (SF), an abundant compound in broccoli sprouts, have been explained by two probable mechanism, a direct effect on $H$.pylori and an indirect effect by triggering the cytoprotective response ${ }^{39}$.

Probiotics are defined as 'live microorganisms, which, when administered in adequate amounts, confer a health benefit on the host'. Using probiotics in the treatment of H.pylori can reduce the side effects and using probiotics more than two week and including lactobacillus significantly enhanced the efficacy of the eradication ${ }^{44}$. Probiotics have shown their positive effects via maintaining gastric mucosal barrier and acidity and providing protection against the harmful effects of H.pylori infection. In addition, probiotics provide a better compliance the treatment as a result of reduced side effects to the intestines ${ }^{45}$. Mechanisms explaining the effects of probiotics on H.pylori are described as; competing against H.pylori on the gastric mucosal epithelium, providing the production of anti H.pylori substances such as acetic acid, propionic acid and butyric acid, supporting the regulation of immune functions and immunoglobulin-A secretion to improve mucosal defensive ability and strengthening the bonds between epithelial cells ${ }^{44}$. Although probiotics have beneficial effects on H.pylori, the impacts on H.pylori eradication are still controversial due to insufficient data on the effctive certain strain and dosage of probiotics ${ }^{46}$.

\section{Nutritional Status After the Eradication of H.pylori}

There are some alterations in gastric hormone levels after the treatment of H.pylori. After the eradication therapy, appetite and body weight had increased due to the elevation of plasma ghrelin ${ }^{47,48}$. Eradication therapy of H.pylori is associated with increased ghrelin levels and growth in children with H.pylori positive ${ }^{49}$.

After the treatment of H.pylori, there are some changes in the blood lipid levels. After the treatment of H.pylori infection, body weight and serum levels of total cholesterol, total protein and albumin had significantly increased. Also reported that incidence of hyperlipidaemia significantly increased and pancreatic function significantly improved ${ }^{50}$.

Some micronutrient malabsorptions improved after the eradication. Eradication therapy with iron supplementation has been found to be better than using only iron supplementation to provide a significant increase serum iron, serum ferritin and hemoglobin levels in H.pylori positive patient with iron deficiency anemia ${ }^{51}$. Also, eradication therapy with iron and folic acid supplementation resulted better than only iron and folic acid supplementation among H.pylori infected pregnant women with IDA $^{52}$. Additionally, H.pylori infection is associated with IDA and after eradication of H.pylori is followed by increasing of serum ferritin and hemoglobin levels in adolescent girls $s^{53}$. In a study, evaluated the efects in homocysteine and cobalamin levels after the eradication of H.pylori, was found that eradication therapy associated with increasing of cobalamin levels and decreasing of homocysteine blood levels in elderly patients with cobalamin deficiency ${ }^{54}$. Eradication of $H$.pylori is effective also in the absorption of vitamin $\mathrm{B}_{12}{ }^{55}$.

\section{Relationships With Other Diseases of H.Pylori Infection}

H.pylori infection is related with chronic gastritis, peptic ulcer, development of gastric cancer. Also, complications of gastrointestinal diseases. H.pylori uses the enzyme urease to convert urea to carbondioxide and ammonia in the stomach. Carbondioxide and ammonia having toxic effect for gastric mucosal epithelial cells and elevating acidic $\mathrm{pH}$ of the gastric lumen and impairing gastric epithelial functions such as mucus secretion. H.pylori is an important risk factor in development of peptic ulcer disease and chronic gastritis due to damage in the gastric mucosa ${ }^{5}$.

H.pylori is effective in the etiology $95 \%$ of duodenal ulcer and $70-85 \%$ of stomach ulcer. Gastric cancer usually develops in atrophic gastritis and the risk of gastric cancer in patients with atrophic gastritis is $5-9$ fold more than the normal population ${ }^{56}$. The issue that the individuals infected with H.pylori develop chronic gastritis is well known, the risk of atrophic gastritis and malignancies is not clear in these patients. However, H.pylori induced stomach ulcers and intestinal metaplasia ${ }^{57}$.

H.pylori is also associated with metabolic syndrome, insulin resistance, diabetes and the development of diabetic complications as well as gastrointestinal disease ${ }^{15}$. The presence of H.pylori infection in patients with diabetes, glucose and lipid absorption is affected by gastrointestinal inflammation induced by H.pylori that may be a risk factor for ensuring blood glucose regulation in diabetic patients ${ }^{58}$. The presence of H.pylori infection in diabetic individuals is associated with microalbuminuria and albumin/creatinine ratio ${ }^{59}$. Additionally, inflammation which is caused by H.pylori is a risk factor for cardiovascular diseases ${ }^{60}$. Some mechanisms such as activation of proinflammatory and vasoactive components, 
production of reactive oxygen species and changed ghrelin and leptin levels may explain the relationship between H.pylori and metabolic syndrome and insulin resistance ${ }^{15}$. H.pylori infection was significantly associated with metabolic syndrome, lower HDL, higher systolic blood pressure and higher LDL levels ${ }^{60}$.

The relationship between H.pylori and obesity is complex. Obesity and metabolic syndrome are based on mostly genetic and lifestyle habits in individuals with H.pylori negative ${ }^{2}$. Some studies are suggested that the risk of H.pylori doesn't increase in obese individuals. Also, the presence of CagA antibodies and H.pylori bacteria have been shown not to be associated with BMI or serum leptin levels $s^{61,62}$. However, increase of appetite and BMI are associated with elevating plasma ghrelin levels after H.pylori eradication ${ }^{47}$.

In the etiology of ischemic heart disease, the H.pylori is one of the frequently investigated issue. It can cause ischemic heart diseases by inducing the platelet activation and aggregation ${ }^{63}$. Also, the presence of folate deficiency is reported to be an another reason for the risk of ischemic stroke and myocardial cases seen in patients with $H$.pylori infection ${ }^{64}$.

Neurological diseases are also thought to be associated with H.pylori. Neurological damage in Parkinson's patients is suggested to be associated with $H$.pylori $i^{15}$. Mitochondrial damage and autoimmunity caused by H.pylori is supposed to play a triggering factor for the mechanisms of Parkinson's disease ${ }^{65}$. There is a relationship between Alzheimer and H.pylori infection ${ }^{66}$ and an improvement in cognitive and functional status in Alzheimer's disease patients in the case of H.pylori eradication was successful ${ }^{67}$.

H.pylori infection plays a role in the pathogenesis of several skin diseases. In particular, the prevelance of H.pylori infection was reported to be high in patients with utricaria and it is associated with an increased risk of chronic urticaria ${ }^{68}$. Acne rosacea, which is associated with H.pylori and gastritis, is another skin disease. H.pylori is associated with the aetiology of rosacea, as a triggering factor and H.pylori eradication treatment provides symptomatic relief in patient with acne rosace ${ }^{64,69}$.

H.pylori infection is related with reduced growth rate in older children and exposure to H.pylori infection in early childhood causes malnutrition and growth retardation in particular in the presence of insufficient food intake ${ }^{70}$. H.pylori infection can lead to a series physiological changes that influence morbidity and mortality in childhood. Hypochlorhydria is associated with H.pylori infection in adults and children. Hypochlorhydria leads to malabsoption of several nutrients and increases susceptibility to enteric infections such as giardiasis, cholera, typhoid and nontyphoidal salmonellosis. These enfections lead to diarrhea which may lead to malnutrition and growth retardation in children ${ }^{2}$.

\section{Conclusion}

H.pylori infection affects $50 \%$ of the world's population with the prevalence being the highest in developing countries ${ }^{1}$. H.pylori is associated with several diseases especially gastrointestinal system disease. In the presence of bacteria, results in malabsorption and malnutrition causing changes in appetite via affecting gastrointestinal hormone levels ${ }^{12,15,19}$. As a consequences of malabsorption, bioavalilability of some micronutrients decreases. In particular iron, vitamin $B_{12}$ and folic acid deficiency seen in patients with H.pylori infection $^{2,43}$. Certain foods and nutrients are effective for the prevention and the eradication therapy of H.pylori. In order to achieve the best results in preventing the disease, promoting healthy diets and lifestyle strategies must fully recognize the essential role of healthy nutrition throughout the entire life course.

\section{References}

1. Dore PM, Marras G, Rocchi C, et al. Changing Prevalence of Helicobacter Pylori İnfection and Peptic Ulcer Among Dyspeptic Sardinian Patients. Int Emerg Medi 2015.

2. Franceschi F, Annalisa T, Teresa DR, et al. Role of Helicobacter Pylori Infection On Nutrition and Metabolism. World J Gastroenterol 2014;20(36):12809-17.

3. Ozaydın N, Turkyilmaz SA, Cali S. Prevelance and Risk Factors of Helicobacter Pylori In Turkey: A Nationally-Representative, Cross-Sectional, Screening with The 13C-Urea Breath Test. BioMed Central Public Health 2013;13:1215.

4. Uyanıkoğlu A, Coşkun M, Binici DN, et al. [Frequency of Helicobacter Pylori In Patients Underwent Endoscopy. ] Dicle Med J 2012;39(2):197-200.

5. Fahey JW, Stephenson KK, Wallace AJ. Dietary Amelioration of Helicobacter Infection. Nutr Res 2015;35(6):461-73.

6. Eusebi LH, Zagari RM, Bazzoli F. Epidemiology of Helicobacter Pylori Infection. Helicobacter 2014;19(1):1-5.

7. Goodman KJ, Correa P, Tengana Aux HJ, et al. Helicobacter Pylori Infection in the Colombian Andes: A Populationbased Study of Transmission Pathways. Am J Epidemiol 1996;144(3):290-9. 
8. Mard SA, Haghighian HK, Sebghatulahi V, et al. Dietary Factors in Relation to Helicobacter pylori Infection. Gastroenterol Res Pract 2014.

9. YanSong Z, MinYan L, Hua S, et al. Relationship Between Oral Problems and Helicobacter Pylori Infection. Arch Oral Biol 2014;59(9):938-43.

10. Santibanez M, Aguirre E, Belda $S$, et al. Relationship Between Tobacco, CagA and VacA il Virulence Factors and Bacterial Load in Patients Infected by Helicobacter Pylori. Plos One 2015;10(4):1-8.

11. Baena JM, Lopez C, Hidalgo A, et al. Relation Between Alcohol Consumption and The Success of Helicobacter Pylori Eradication Therapy Using Omeprazole, Clarithromycin and Amoxicillin For 1 Week. Eur J Gastroenterol Hepatol 2002;14(3):291-96.

12. Konturek PC, Czesnikiewicz-Guzik M, Bielanski W, et al. Involvement of Helicobacter Pylori Infection In NeuroHormonal Control of Food Intake. J Physiol Pharmacol 2006;57(5):67-81.

13. Boyanova L, Ilieva J, Gergova G, et al. Honey and Green/Black Tea Consumption May Reduce The Risk of Helicobacter Pylori Infection. Diagnostic Microbiol Infect Disease 2015;8 2(1):8586.

14. Güvenir M, Yılmaz Ö. The World of Helicobacter Pylori Signal Pathways. Tr Mikrobiyol Cemiyeti Derg 2009;39(3-4):115121.

15. Wong F, Rayner-Hartley E, Byrne MF. Extraintestinal Manifestations of Helicobacter pylori: A Concise Review. World J Gastroenterol 2014;20(34):11950-61.

16. Özen Ş. Exercise, Appetite, Food Intake and Ghrelin: Review. Türkiye Klin Spor Bil Derg 2012;4(1):43-54.

17. Gil-Campos M, Aguilera CM, Cañete R, et al. Ghrelin: A Hormone Regulating Food Intake and Energy Homeostasis. $\mathrm{Br}$ J Nutr 2006;9 6:201-26.

18. Asakawa A, Inui A, Fujimiya M, et al. Stomach Regulates Energy Balance via Acylated Ghrelin and Desacyl Ghrelin. Gut 2005;54:18-24.

19. Chen C, Inuı A, Asakawa A, et al. Des-acyl Ghrelin Acts by CRF Type 2 Receptors to Disrupt Fasted Stomach Motility in Conscious Rats. Gastroenterol 2005;129:8-25.

20. Gao XY, Kuang HY, Liu XM, et al. Circulating Ghrelin/ Obestatin Ratio in Subjects with Helicobacter Pylori Infection. Nutr 2009;25(5):506-11.

21. Boltin D, Niv Y. Ghrelin, Helicobacter Pylori and Body Mass: Is There an Association? Israel Med Association J 2012;14(2):13032.

22. Jang EJ, Park SW, Park JS, et al. The İnfluence of the Eradication of Helicobacter Pylori on Gastric Ghrelin, Appetite, and Body Mass Index in Patients with Peptic Ulcer Disease. J Gastroenterol Hepatol 2008;23(2):278-85.

23. Salles N, Menard A, Georges A, et al. Effects of Helicobacter Pylori Infection on Gut Appetite Peptide (Leptin, Ghrelin) Expression in Elderly Inpatients. J Gerontol Biol Sci 2006;61(11):1144-50.
24. Javadi L, Gargari BP, Salekzamani S, et al. Folate and Homocysteine Levels and Their Association with Dietary Intakes in Iranian Patients Infected with Helicobacter Pylori: a Case-Control Study. Acta Med Iranica 2015;53(3):162-67.

25. Gümürdülü Y, Serin E, Özer B, et al. Predictors of Vitamin B12 Deficiency: Age and Helicobacter Pylori Load of Antral Mucosa. Tr J Gastroenterol 2003;14(1):44-49.

26. Annibale B, Capruso G, Martino G, et al. Iron Deficiency Anaemia and Helicobacter Pylori İnfection. International J Antimicrobial Agents 2000;16(4):515-19.

27. Drvishi M, Ziari K, Mohebi H, et al. Association Between Iron Deficiency Anemia and Helicobacter Pylori Infection Among Children Under Six Years in Iran. Acta Med Iranica 2015;53(4):220-24.

28. Malfertheiner P, Megraud F, O’Morain C, et al. Current Concepts in The Management of Helicobacter Pylori Infection: The Maastricht III Consensus Report. Gut 2007;56:772-81.

29. Annibale B, Capurso G, Delle Fave G. Consequences of Helicobacter Pylori İfection on The Absorption of Micronutrients. Digest Liver Dis 2002;34(1):572-77.

30. Salgueiro J, Zubillaga M, Goldman C, et al. Review Article: Is There a Link Between Micronutrient Malnutrition and Helicobacter Pylori Infection? Alimentary Pharmacol Therap 2004;20:1029-34.

31. Park JH, Kim SY, Kim DW, et al. Correlation Between Helicobacter Pylori Infection and Vitamin C Levels in Whole Blood, Plasma and Gastric Juice and The $\mathrm{pH}$ of Gastric Juice in Korean Children. J Pediatr Gastroenterol Nutr 2003;37(1):5362.

32. Pal J, Girija Sanal M, Gopal J. Vitamin-C as anti-Helicobacter Pylori Agent: More Prophylactic Than Curative- Critical Review Indian J Pharmacol 2011;43(6):624-27.

33. Devrajani B, Zaman, MS, Shah $S$, et al. Helicobacter pylori: A Cause of Vitamin B12 Deficiency. World App Sci J 2011;12(9):1378-81.

34. Serin E, Gümürdülü Y, Ozer B, et al. Impact of Helicobacter Pylori on The Development of Vitamin B12 Deficiency in The Absence of Gastric Atrophy. Helicobacter 2002;7(6):337-41.

35. Kaptan K, Beyan C, Ural AU, et al. Helicobacter Pylori -Is it a Novel Causative Agent in Vitamin B12 deficiency? Arch Intern Med 2000; 160:1349-53.

36. Tang G, Serfaty C, Camilo M, et al. Gastric Acidity Influences The Blood Response to a Beta-Carotene Dose in Humans. Am J Clin Nutr 1996;6 4:622-26.

37. Yakoob J, Jafri W, Abid S. Helicobacter Pylori Infection and Micronutrient Deficiencies. World J Gastroenterol 2003;9(10):2137-39.

38. Mabe K, Yamada M, Ogunı I, et al. In Vitro and in Vivo Activities of Tea Catechins against Helicobacter Pylori. Antimicrobial Agents and Chemotherapy 1999;43(7):1788-91.

39. Ayala G, Escobedo-Hinojasa WI, Cruz-Herrera CF, et al. Exploring Alternative Treatments for Helicobacter Pylori Infection. World J Gastroenterol 2014;20(6):1450-69. 
40. Lee S, Kang D, Shim KN, et al. Effect of Diet and Helicobacter pylori Infection to the Risk of Early Gastric Cancer. J Epidemiol 2003;1 3:162-68.

41. Sachdeva A, Rawat S, Nagpal J. Efficacy of Fermented Milk and Whey Proteins in Helicobacter Pylori Eradication: A Review. World J Gastroenterol 2014;20(3):724-37.

42. Keenan JI, Salm N, Hampton MB, et al. Individual and Combined Effects of Foods on Helicobacter Pylori Growth. Phytotherapy Res 2010;24:1229-33.

43. Keenan JI, Salm N, Wallace AJ, et al. Using Food to Reduce H.Pylori-Associated Inflammation. Phytotherapy Res 2012;26:1620-25.

44. Lv Z, Wang B, Zhou X, et al. Efficacy and Safety of Probiotics as Adjuvant Agents for Helicobacter Pylori Infection: A Meta-Analysis. Exp Therapeutic Med 2015;9:707-16.

45. Lesbros-Pantoflickova D, Corthesy-Theulaz I, Blum AL. Helicobacter Pylori and Probiotics. J Nutr 2007;137(2):81218.

46. Cremonini F, Canducci F, Caro SD, et al. Helicobacter Pylori Treatment: A Role for Probiotics. Digestive Diseases 2001;19:144-47.

47. Nwokolo CU, Freshwater DA, O'Hare P, et al. Plasma Ghrelin Following Cure of Helicobacter Pylori. Gut 2003;52:637-40.

48. Azuma T, Suto H, Ito Y, et al. Eradication of Helicobacter Pylori Infection Induces an Increase in Body Mass Index. Alimentary Pharmacol Therap 2002;16(2):240-44.

49. Yang YJ, Sheu BS, Yang HB, et al. Eradication of Helicobacter Pylori Increases Childhood Growth and Serum Acylated Ghrelin Levels. World J Gastroenterol 2012;18(21):2674-81.

50. Furuta T, Shirai N, Xiao F, et al. Effect of Helicobacter Pylori Infection and Its Eradication on Nutrition. Alimentary Pharmacol Therap 2002;16(4):799-806.

51. Huang X, Ou X, Yan W, et al. Iron Deficiency Anaemia Can be Improved After Eradication of Helicobacter Pylori. Postgraduate Med J 2010;86:272-78.

52. Malik R, Guleria K, Kaur I, et al. Effect of Helicobacter Pylori Eradication Therapy in Iron Deficiency Anaemia of Pregnancy A Pilot Study. Indian J Med Res 2011;134:224-31.

53. Xia W, Zhang X, Wang J, et al. Survey of Anaemia and Helicobacter Pylori Infection in Adolescent Girls in Suihua, China and Enhancement of Iron Intervention Effects by H.Pylori Eradication. Br J Nutr 2012;108(2):357-62.

54. Marino MC, Oliveira CA, Rocha AM, et al. Long-Term Effect of Helicobacter Pylori Eradication on Plasma Homocysteine in Elderly Patients with Cobalamin Deficiency. Gut 2007;56(4):469-74.

55. Kaptan K, Beyan C, Ural AU, et al. Helicobacter pylori- Is It a Novel Causative Agent in Vitamin B12 Deficiency? Arch Int Med 2000;160:1349-53.
56. Yılmaz Ö, Okçu N. Helicobacter Pylori and Related Gastrointestinal System Diseases. Atatürk Üniv Tip Derg 2006;38:13-17.

57. Hirayama F, Takagi S, Kusuhara H, et al. Induction of Gastric Ulcer and Intestinal Metaplasia in Mongolian Gerbils Infected with Helicobacter Pylori. J Gastroenterol 1996;31:755-57.

58. He C, Yang Z, Lu NH. Helicobacter Pylori Infection and Diabetes: Is It a Myth or Fact? World J Gastroenterol 2014;20(16):4607-17.

59. Chung GE, Heo NJ, Park MJ, et al. Helicobacter Pylori Seropositivity In Diabetic Patients Is Associated with Microalbuminuria. World J Gastroenterol 2013;19(1):97-102.

60. Gunji T, Matsuhashi N, Sato H, et al. Helicobacter Pylori Infection is Significantly Associated with Metabolic Syndrome in the Japanese Population. Am J Gastroenterol 2008;10(12):3005-10.

61. Cho I, Blaser MJ, François F, et al. Helicobacter Pylori and Overweight Status in the United States: Data from the Third National Health and Nutrition Examination Survey. Am J Epidemiol 2005;162:579-84.

62. Ioannou GN, Weiss NS, Kearney DJ. Is Helicobacter Pylori Seropositivity Related to Body Mass Index in the United States? Alimentary Pharmacol Therap 2005;21:765-72.

63. Elizalde JI, Gomez J, Panes J, et al. Platelet Activation in Mice and Human Helicobacter Pylori Infection. J Clin Invest 1997;100:996-1005.

64. Yilmaz K. Relationship Between Helicobacter Pylori and Disorders Out of Gastrointestinal System. Cumhuriyet Üniv Tip Fak Derg 2001;23(2):105-09.

65. Dobbs RJ, Dobbs SM, Weller C, et al. Helicobacter Hypothesis for Idiopathic Parkinsonism: Before and Beyond. Helicobacter 2008;13:309-22.

66. Malaguarnera M, Bella R, Alagona G, et al. Helicobacter Pylori and Alzheimer's Disease: a Possible Link. Eur J Int Med 2004;15:381-86.

67. Kountouras J, Boziki M, Gavalas E, et al. Eradication of Helicobacter Pylori May Be Beneficial in The Management of Alzheimer's Disease. J Neurol 2009;256:758-67.

68. Gu H, Li L, Gu M, et al. Association Between Helicobacter Pylori Infection and Chronic Urticaria: A Meta-Analysis. Gastroenterol Res Pract 2015.

69. Kutlubay Z, Zara T, Engin B, et al. Helicobacter Pylori Infection and Skin Disorders. Hong Kong Med J 2014;20:317-24.

70. Perri F, Pastore M, Leandro G, et al. Helicobacter Pylori Infection and Growth Delay in Older Children. Arch Disease Childhood 1997;77:46-49. 